\title{
Hybrid Affects of Religious Nationalism: Pilgrimages to Kosovo and the Soundscapes of the Utopian Past
}

\author{
Srđan Atanasovski \\ Institute of Musicology SASA, Belgrade \\ srdjanatanasovski@yahoo.co.uk
}

\begin{abstract}
In this paper I analyze the contemporary practice of Serbian pilgrimages to Kosovo, which have been on the rise in the aftermath of the Kosovo Declaration of Independence. Designating the Serbian pilgrimage to Kosovo as a hybrid affective experience, I investigate how sentiments of religion and nation interact through the media of sound and music, pointing out the role of the shared lived experience of the community. I discuss how affects, which are alternately produced by the social machines of religion and of nation, become hybridized and synergistically reinforced in situ, not only relying on discursive games and strategies, but also on the immediacy of the lived 'truth'. I emphasize in particular the role of musical experience in this process, showing how music activates mnemonic processes and provokes affects in the community as it is uncritically inscribed on the bodies of the individuals through both communal music-listening and music-making.
\end{abstract}

\section{Keywords}

Kosovo - sonic affect - pilgrimage - religious nationalism - production of space (H. Lefebvre)

\footnotetext{
* The paper was written as a part of the project Serbian Musical Identities within Local and Global Frameworks: Traditions, Changes, Challenges (no. 177004 /2011-2014/) funded by the Ministry of Education and Science of Republic of Serbia. I hereby thank the guest-editor, Ana Hofman, for her immense dedication, as well as Ian MacMillen, Andrija Filipović, Dave Wilson, and two anonymous reviewers for their valuable advice in the editing process.
} 
Scene 3. Saturday evening. The four of us come to the porch of the family home in the Kosovo village of Velika Hoča, where we are to spend the night, after a long bus ride from Belgrade and a communal dinner in the parish house. We are all fairly young, in our twenties. None of us has been to Kosovo before. On the bus that day I sat with the most pious of us, while the other two know each other from their faculty. The host brings out rakija and serves. The devout companion remains mostly silent and cannot drink, as he fasts and is to receive the Holy Communion in the morning, in the medieval monastery of Visoki Dečani. He is particularly looking forward to the service in the monastery, as he likes the manner in which the monks do the service, using 'Byzantine chant', and he has been listening to monks chant during the trip that day on his portable media player. He prefers the service with the 'Byzantine chant' as he believes it is more faithful to the ancient traditions of Christianity, although it is officially not condoned in the Serbian Orthodox Church. The wife of the host sits with us, while the daughter leaves the house seemingly in a hurry, which raises doubts regarding her hospitality in the eyes of my companions. The most talkative of the four of us (one of the two faculty colleagues) leads the conversation, together with the host; the former relates how he feels about visiting Kosovo, the 'holy land', while the latter narrates the vicissitudes of his life in Velika Hoča. The traveller insists that the holiness of the land can be sensed in the earth, in the air, as an unutterable feeling. The host tells us how the number and influence of the Albanian population in the area has risen during his lifetime, which makes him feel threatened. Albanians are not to be trusted. His greatest sorrow is that the statehood of Serbia doesn't reach his land. They agree that the cohabitation with the Albanian population is utterly impossible, meeting with a tacit approval from the rest of the company. The pious companion goes to bed early. Finally the three of us go to sleep, too, sharing a room on the ground floor, agreeing beforehand on the time for which to set our alarm clocks, so that we can have enough time to get ready and meet with the rest of the travellers to continue our journey to Visoki Dečani. In the morning, we are awakened by the cell phone alarm of the talkative companion, which plays the song Srpska se truba s Kosova čuje ('The Serbian trumpet resounds from Kosovo'). 
The aim of this article is to show how religious nationalism is inscribed into the bodies of individual subjects through sound practices on the level of lived experience, overriding the mediation of ideological and identity discourses through a process I call the hybridization of affect. My approach starts off with the Deleuzo-Guattarian assumption of immanence - the idea that social reality unfolds in the material immediacy that surrounds us, and that in order to understand it we have to move beyond the concepts of ideology and identity that, unless understood as strictly regulative concepts, presuppose a plane of transcendence (cf. Brubaker and Cooper 2000). As I deal with notions of nation, religion, and homeland, I wish to bring them to the level of quotidian affective practices and to show how they operate as complex assemblages, an abstract desiring-machine regulating the flows of intensities on the body of the socius (cf. Deleuze and Guattari 1983, 1987). ${ }^{1}$

Pilgrimage is one of the paradigmatic situations in which the affective economies of nationalistic practices can be studied in detail. ${ }^{2}$ As a form of 'brute mobility' (Cresswell 2006: 3-4), a 'kinetic ritual' (V. Turner and E. Turner 1978: xiii), pilgrimage is itself a series of encounters, a myriad of molecular moments in which our interaction with a space collides with the material images and ideas socially produced on/in this space, creating crevices on the body of the socius and allowing for the social meaning to be inscribed in the lived affective experience. As a journey invested with religious meanings, it is where the religious

1 Deleuze and Guattari introduced the concept of desiring-machine in order to describe machinic social production of the object of desire, which is understood not as a psychoanalytical 'lack', but as something positive and productive, as well as de-sexualized and de-individualized (Deleuze and Guattari 1983: 1-50; Parr 2005: 63-6). Furthermore, Deleuze and Guattari complement the idea with the concept of socius, the 'full body [which] forms a surface where all [desiring and social] production is recorded' (Deleuze and Guattari 1983: 10), a 'megamachine', the terrain of the coding and recoding of the desire, which is necessary in order to enable subjects to engage in their social roles and functions (Parr 2005: 255-7).

2 Pilgrimages studies have been a burgeoning field since the late 1970s, and they can be recognized as a sub-discipline of cultural anthropology since the 199os. The decisive breakthrough was made by the British cultural anthropologist Victor Turner, who interpreted pilgrimage as a 'liminoid' ritual and particularly studied the shared, communal experience of the pilgrimage (Turner 1973; V. Turner and E. Turner 1978). A retort was articulated in the 1990 s by a group of scholars who saw a pilgrimage not as a rite that creates communitas, but as a terrain of contestation, where the differences of identities become more pronounced than in everyday life (Eade and Sallnow 1991; Coleman and Eade 2004; cf. Coleman 2002). In my paper I position myself closer to Turner's idea of communitas, albeit not in a sense of identity-building but as a form of transient affective economy (Ahmed 2004), constituted on the level of sensory experience. For regional and Serbian Orthodox perspectives on pilgrimage studies cf. Radulović 2010, Radisavljević Ćiparizović 2010, 2012, Belaj 2012, and Sikimić 2014. 
body - the body formed through religious body management - encounters the body of the memory, understood as an assemblage of material practices and objects that trigger the mnemonic processes.

By focusing on the role of music in a participative event such as a pilgrimage, where affects ${ }^{3}$ are generated and transmitted through a group, it is possible to demonstrate the differential nature of this process of inscription, which is shaped by social discourses but is also dependent on phenomenal, bodily experience. Here I am also impelled to rethink the ontological status of 'cultural memory', arguing that it does not exist in the transcendent realm of the symbolic, but in material immanence, which enables it to affect our lived experience. The materiality of the sites of memory has recently been pointed out by memory studies scholars, most notably by Pierre Nora (1989). In an exciting circular essay, Pierre Clastres (1973) also showed how memory inscribes itself into the body through a circuit of law, writing, ritual, and torture.

In the course of my account I will use the concepts elaborated in Henri Lefebvre's tri-dimensional model of the production of space (Lefebvre 1991; cf. Goonewardena et al. 2008). Unlike in the works of Deleuze and Guattari (1987), where space always remains on the verge of metaphor, Lefebvre analyses its immediate reality, as both the locus and actor in social processes (Purcell 2013). I see the Lefebvrian approach as helpful in the endeavour to portray society in its immanent unfolding. Lefebvre, perhaps more strongly and adamantly than any other modern philosopher, strives to bring notions of discursive and symbolic order back into material reality and to show how they operate on the level of lived experience. Distinguishing between three modalities of spatial experience, Lefebvre construes the social production of space through a tridimensional dialectic, where the level of 'lived space' ('representational space') emerges through the juxtaposition of the 'spatial practice' ('perceived space') and the 'representations of space' ('conceived space'). ${ }^{4}$ Lefebvre's spatial dialectics teaches us that lived space is not produced as a synthesis of 'spatial

3 The concept of affect that I use is being developed in post-Deleuzo-Guattarian affect studies, where 'affect' is equated with pure intensity, ontologically different from 'emotion', and its transmissibility and non-personal/non-human traits are particularly being stressed (cf. Massumi 2002; Brennan 2004; Seyfert 2012).

4 Unlike Deleuze and Guattari, Lefebvre often articulates his philosophy through the ironic use of the terms he intends to criticize. The ironic pairing of 'representations of space' and 'representational space' is itself a critique of the semiotic concept of 'representation' and is designed to subvert it. Hence, I would argue that these two terms (which I will mark off throughout with quotation marks) are compatible with the Deleuzo-Guattarian notion of immanence, showing that 'transcendence is relative and represents no more than an "absolutization of immanence"' (Deleuze and Guattari 1994: 74). 
practice' and 'representations of space' in a Hegelian dialectical system; rather, it is reached through an affective and laborious process where these two practices are spatially juxtaposed in the materiality of everyday life. Lived space thus remains riven with contradictions and ambivalences that are produced through this spatial juxtaposition, or through a series of spatial encounters. 'Spatial practice' refers to the actual material flows that occur in the actual space and, as such, it is quintessentially motility, conatus ad motum in its most material and immediate emanation. ' 'Representations of space', or the 'conceived space', speak of space as it is conceived in social discourse, but also point out the materiality of these discourses - the 'representations of space' are themselves spatial, and it is only their spatial and material occurrence that enables them to act, to embody agency (or to affect, in a Spinozian sense). In other words, social reality is ultimately material and spatial, and the act of its production is performed through a stochastic process of juxtaposition that always remains open.

Designating Serbian pilgrimage to Kosovo as a hybrid experience, I have tried not only to study the obvious twofold nature of this event as both a religious experience and a manifestation of nationalistic sentiments, but also to examine the mechanism involved in the production of social meaning. Investigating how the sentiments of religion and nation interact, I do not trace their linkage at the discursive level, but instead point out how highly affective this connective tissue is, being dependent on the shared lived experience of the community. In this way, the affects that are alternately produced by the social machines of religion and of nation become hybridized and synergistically reinforced in situ, not only relying on discursive games and strategies, but also on the immediacy of the lived and the experienced 'truth'. I emphasize particularly the role of musical experience in this process, showing how music provokes affects that are being uncritically inscribed on the bodies of individuals, through both communal music-listening and music-making. In contemporary affect studies, music is often singled out as having a 'mobilizing capacity', and I am specifically interested in analyzing its capacity to transmit an

5 Spinoza employs 'conatus', a technical term of Cartesian physics, to describe 'the essence of any finite mode, including any human mind' as 'a striving [...] to persevere in being'; conatus ad motum is understood as a purely material striving for motion, divested of mental properties; in Spinoza's words, '[b]y striving for motion we do not understand any thought, but only that a part of matter is so placed and stirred to motion, that it really would go somewhere if it were not prevented by any cause' (LeBuffe 2014; cf. Rocca 1996; Cook 2011). The term has been revitalized by Deleuze (Deleuze 1988; 1990) and reappropriated in contemporary affect theory (cf. Lordon 2014). 
"energy", which is 'unlocked by its use in particular space' (Thompson and Biddle 2013b: 5) and thus regulated not only by the 'meaning' of a particular music-work itself, but also by the sheer sonic intensity produced in the specific context.

Although the phenomena related to post-Yugoslav memory practices - such as Yugo-nostalgia, competing memory narratives of the past, war, and their role in reconciliation, etc. - usually do not revolve around Kosovo, creating the impression that the dissolution of socialist Yugoslavia was mainly the matter of Serbs, Croats, and Bosnians ('Muslims', in the official discourse of the socialist Yugoslavia), which also shared a common pluricentric language standardized under the name of 'Serbo-Croatian', one could argue that the spectre of the Kosovo issue and Serbian-Albanian relations haunted the belligerent dissolution of Yugoslavia from its onset (cf. Maliqi 2011). Thus, the proliferation of Serbian nationalistic discourse, which was to wreak havoc in the early 199os, was closely connected with the situation in Kosovo in the 1980 s. The rise of a strong nationalistic Serbian political elite directly resulted in the so-called Anti-Bureaucratic revolution, which toppled the Albanian Kosovo leadership and thoroughly revised the federal constitution of Serbia in order to curb the self-governing rights of Kosovo. ${ }^{6}$ After being stifled and ignored during the wars in Croatia and Bosnia, the unresolved issues in Kosovo burst during the Kosovo war (fought in 1998-99), resulting in the removal of Kosovo from under the control of Serbian administration, which proved to be the final epilogue of the wars in socialist Yugoslavia.

\section{In the Circuit: Nationalism - Space - Religion - Body - ...}

Scene 2. Saturday early morning, 6 AM. The music played on the bus is Orthodox Christian chants. People notice the landmarks of the other religion and nation (such as minarets and Albanian flag) in the landscape through which we pass and react with anger or irony. We are heading to

6 Kosovo played a crucial role in the Anti-Bureaucratic revolution, a series of events in 1988 and 1989 arranged to curb the power of the administrations of the Autonomous provinces of Vojodina (northern Serbia) and Kosovo, in order to override the 1974 constitution of Socialist Yugoslavia, which curtailed the direct rule of Serbian administration. The main impetus was the demand of Serbs from Kosovo to prevent what they perceived as discriminatory politics of the Kosovo administration, which reflected the Albanian majority in the province. The climax of this 'revolution' was the staged celebration of the battle of Kosovo on the $28^{\text {th }}$ of June 1989 in Gazimestan, the site of the battle, with reported attendance of between one and two million people who came from throughout the country (Sundhaussen 2007: 409-11). 
the church Samodreža, purportedly the place where prince Lazar and his army had the last Holy Communion before the Kosovo battle in 1389. We are told that it is safer to go there in this hour, when the villages are dormant, as the area is off the track and completely inhabited by Albanians. 'Our goal is to bring the Serbian footing back to Samodreža.' We find the church devastated and abandoned. We continue our trip accompanied by the sounds of the chants of Russian monks. A traveller notes the music, telling his companion softly that he finds the music pleasing. She approves.

Based on its alleged core position in the Serbian medieval state, its importance as the site of the battle between the Ottoman army and Serbian nobility in the fourteenth century, and its cultural legacy embodied in the network of orthodox Christian monasteries, Kosovo has been constructed as the 'cradle' of the Serbian nation and the core part of its territory for more than a century. ${ }^{7}$ Moreover, as the 'core territory' (White 2000: 39-41), the threatened part of the homeland though which the nation is being defined, Kosovo has stood as a synecdoche for the Serbian homeland and nation itself. Although the Kosovo myth was basically invented and drawn to its climax in the late nineteenth and twentieth centuries, its perpetual 'becoming' is always mystified and ahistorical. ${ }^{8}$ After the rise of nationalistic discourse in socialist Yugoslavia in the 1980s, the particular importance of Kosovo was again due to various manifestations serving to celebrate the six hundred year anniversary of the Battle of Kosovo. The celebration in 1989 engendered various artistic productions, ranging from the state produced historical film Boj na Kosovu ('Battle of Kosovo', directed by Zdravko Šotra) to an array of variously produced patriotic songs. The role of Kosovo as the core Serbian homeland was also performed through strategies

7 I am drawing on the concept of 'core national territory', formulated by George W. White (2000) in his investigation of the role of territory in Southeast-European nationalisms, as a part of national territory that is most deeply imbued with the historical memory. The status of Kosovo was particularly important in the decades leading to the First Balkan War (1912-13), when the Kingdom of Serbia and Montenegro allied with Bulgaria and Greece in an effort to drive the Ottoman Empire out of the Balkans. The myth of Kosovo, centred on the Kosovo Battle, mobilized the sentiments and gave impetus to the idea of revenge for the Serbian soldiers who were defeated more than five centuries before.

8 The resurrection of the Kosovo myth in the 8os was not only performed through the misinterpretations of the historical events, but it also contained a strong and affective line of solidarity with the real and alleged sufferings of the Serbian minority in Kosovo, which has been subjected to various - although in the media often exaggerated - discrimination by the Albanian majority (cf. Sundhaussen 2007: 390-92). 
of cultural memory - cultural artefacts, political rhetoric, staged events and rituals, and it acted as a never ending desiring-machine that generated affective practices in Serbian society. This always entailed spatial practices and the material distribution of certain cultural artefacts.

In the way that contemporary Serbian pilgrimages to Kosovo combine nationalistic and religious imagery, they fit within the post-Milošević Serbian society, which is marked by the employment of the symbols and practices of the Serbian Orthodox Church in embodying the values of the nation. ${ }^{9}$ While the current constitution defines Serbia as 'the state of Serbian nation and all the citizens that inhabit it', the Serbian nation is perpetually and unambiguously defined through Orthodox Christianity. The contemporary rhetoric of the Serbian Church and its opaque national-religious doctrine of svetosavlje overrides the traditional pan-national, ecumenical character of Christianity and represents itself as the ultimate and unique bearer of Serbian national identity through history. ${ }^{10}$ With the introduction of religious education in the school system and the strong ties between the realm of politics and the realm of faith, the rituals of the state and the Church have become inseparably intertwined after 2000 (cf. Malešević 2011). It is particularly important to investigate nationalism in Serbia as religious because the relationship between religious practices and nationalistic ideology does not remain on the level of a disembodied discourse. Rather, religious practices have throughout history been one of the most intimate meeting points between the subject's body and society. Religion appears on the level of the body of the believer, and it mediates the subject's body and society. ${ }^{11}$ Its strategies of biopolitics - of sex, eating, clothing, and gestures - regulate and reterritorialize the national subject on its most personal, bodily level. Thus, the hybrid lived experience of religion and nation,

However, the role that Orthodox Christianity and its affective practices have recently assumed in the expression of Serbian nationalism could not have been possible without the strongly articulated historical ties between these two assemblages. From its inception, Serbian nationality has been conceptualized as a religious nationality (cf. Friedland 2001, Brubaker 2011), tied with the idea of belonging to Orthodox Christianity.

10 In the words of priest Dimitrije Najdanović, svetosavlje is defined as 'particular, independent and special encounter and mystical connection of the Serbian national soul with Christ' (Najdanović 2009: 22; cf. Sundhaussen 2007: 289-92; Bakić-Hayden 2010: 60-61).

11 An exemplary study for the relationship between religious authority and the body is Peter Brown's The Body and Society, which focuses on the practices of sexual abstinence in early Christianity (Brown 1988; cf. Carrette 1999, Haag and Bauman 2012). Mitrović (2011) examines how religion, nationalism, and class become intertwined in the realm of gender performativity in contemporary Serbia. 
which occurs through the affective economies of events such as the Kosovo pilgrimage, allows national subjectification to be performed through practices that are primarily religious.

As this hybridized lived experience happens in the juxtaposition of the pilgrim's 'brute mobility' and the 'representations of space', the latter ultimately act as 'lieu de memoire' (Nora 1989). The body of the representation, whether it is the body of an individual, a landmark, or an engineered landscape, is itself the embodied memory. In order for religious nationalism to affect our practices and produce subjects, it has to exist on the level of material immanence, on the level of 'representations of space'. The materiality of the memory is thus inscribed in the landmarks, in the buildings, but also in the institutions, in the rituals, and ultimately in the discourse consisting of institutionalized texts that offer interpretations of reality. The body of the religious nation is an ultimate machine of memory as it draws on the resources of both the state apparatus and the religious apparatus to shape bodily practices: from the athletic body, through the educated and cultivated body, to the body that fasts, the body that prays, and the body that delimits its sexual activities according to religious prescripts, the practices of body management become the practices of nationalism. And in the process, these practices also become the place of national memory. The body that prays becomes the body that remembers holy medieval kings, the body that fasts becomes the body that remembers the body of the holy martyrs. The 'body' is therefore no longer the body of the individual but is the body of the socius, connected through the laborious and affective practice of body management, through which memory becomes immediate and thereby affects our lived experience.

\section{'Serbian Jerusalem': Kosovo on a Pilgrims' Route}

Scene 1. Friday evening. I arrive at the bus stop near the plateau of the Saint Sava Temple in Belgrade as the other travellers also gather around the double-decker bus. Some of them come in groups, some are solitary. Some are here to bring food supplies to be carried to Kosovo for the poor, or to wish a happy travel to friends and family members. When settled in the bus, the leader of the trip gives us the printed plan of the trip and rules of behaviour. At 22:35 the bus sets off and the leader address us through the speakers as 'brothers and sisters' and reads the prayer for the trip. He explicates the meaning of the trip - it is a holy pilgrimage in the 
time of fasting, and we are going to pay homage to holy places and shrines. This is an endeavour fraught with risk - there is no such tour among the offerings of touristic agencies, and due to recent events the threat is even higher. But we go with faith in God, as representatives of 'northern Serbia'. We are strictly forbidden to enter into any communication with the Albanian population.

Although pilgrimages ${ }^{12}$ have become a popular way of traveling for Orthodox Christian devotees in Serbia in the past decades, none of the official travel agencies conducts trips to Kosovo, due to its disputed status and the possible security risks that are involved in the enterprise. Purportedly a religious practice, pilgrimages to Kosovo were initiated only in the aftermath of the Kosovo War (1998-99), when the territory was excluded from the administration and sovereignty of the Republic of Serbia and governed as an international protectorate. In the beginning, several organizations conducted the trips, including the conservative journal Geopolitika (published in Belgrade since December 2000). However, after the Declaration of Kosovo independence in February 2008, followed by violent demonstrations in Belgrade, the relations between Kosovo and Serbia have become burdened and administratively difficult, and, as a result, official organizations have ceased being involved in these trips. Since then, the pilgrimages have been organized exclusively by a semi-private enterprise, formally registered as a 'student organization', with the blessing of the Serbian Orthodox Church. The activities of this organization are not transparent and they are practically led by a single person, who organizes and leads the trips himself. The advertising is conducted through simple amateur black-and-white posters, which are placed in the vicinity of the Orthodox churches, though in the last few years they have become abundant throughout Belgrade. The posters regularly feature the map of Kosovo as a part of Serbia and highlight the religious landmarks. Interestingly, there is no online advertising, but promotion is also vigorously conducted through mobile phone SMS services. The price of the trip is 45 euros (approximately $12 \%$ of the average monthly wage in Serbia), and the trips are usually conducted ten times per year, once per month, with a winter break from midDecember to early March.

12 The phrase used in Serbian is more often pokloničko putovanje (in this sense, journey of humble worship) instead of hodočašće, which some believe is reserved only for travel to the Holy Land. 


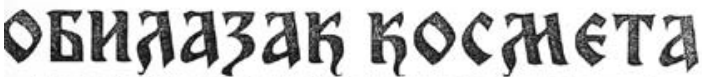 - август 2011(слава аєчана) -}

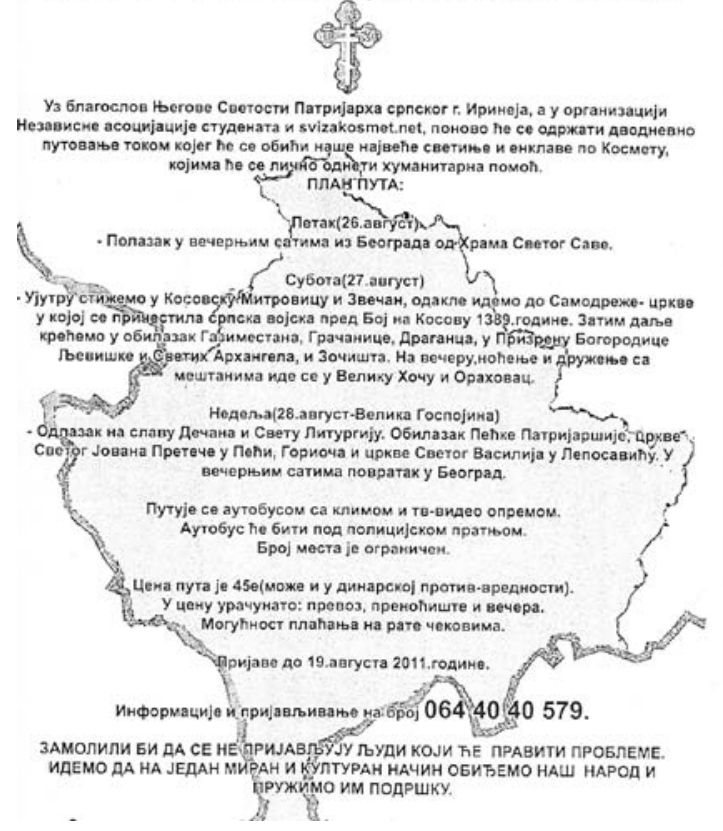

ILLUSTRATION 1 The promotional poster for the August pilgrimage in 2011. PHOTO BY THE AUTHOR

The research presented in this paper is based on fieldwork conducted in August 2011. ${ }^{13}$ The significant feature of this pilgrim trip was that it was performed in the midst of a turbulent situation in northern Kosovo, which compromised its security. During the 2011 North Kosovo crisis, special police forces of Priština tried to seize the 'border posts'/'administrative checkpoint'14 between northern Kosovo and Serbia (Serbia proper), resulting in a violent clash between Kosovo police, NATO troops, and the Serbian population, with casualties reported.

13 The basic methodology of the fieldwork is participant observation. The aim was to study the affective economy of the pilgrimage on the field (with minimal intervention from the researcher) and to document the role of music practices. I have also conducted interviews with selected pilgrims; however, the main objective of these interviews has been data mining rather than to invite the interlocutors to describe their experiences verbally a posteriori.

14 This dispute in terms puts you on the Albanian or Serbian side of the conflict. 
Accordingly, the latter decided to block the roads and to use illegal 'alternative' crossings to communicate with Serbia. In light of these events, the importance of security warnings and of police accompaniment was heightened.

Departing on the evening of the $26^{\text {th }}$ of August, heading off from the capital city of Belgrade, the tour offered travellers a chance to visit the sites of national imagery and the most famous medieval Orthodox churches, as well as some newly built churches with small, albeit thriving communities. On Saturday the pilgrims visited the church Samodreža, Gazimestan, ${ }^{15}$ and the monasteries Gračanica and Draganac, both in Serbian enclaves. On the way to Prizren the bus broke down and the travellers were forced to wait in the field next to the road for the drivers to fix the malfunction. As this happened in the Drenica region, notorious for the atrocities committed by the Serbian armed forces during the Kosovo War of 1998-99, we were particularly warned not to disperse or leave the vicinity of the bus, despite the uncomfortable scorching summer sun. Because of this, the visit to Prizren was abandoned, and the tour continued to the monastery of Zočište in western Kosovo, and then to Velika Hoča, where dinner and accommodations had been arranged. On Sunday morning, with some delay, pilgrims arrived at the Holy Service and Communion at the monastery of Visoki Dečani. It was the monastery's feast day and the service was well attended, with many Serbs from the surrounding area coming to the monastery. Afterwards we were welcomed by the monks to the monastic quarters with a modest serving of food and drinks. Journeying farther, travellers visited Peć monastery (which is also the nominal seat of the Serbian patriarch), the church in the city of Peć, and the newly restored monastery of Gorioč and church of Saint Vasilije in the town of Leposavić. In the early evening the bus headed back to Belgrade, arriving after midnight.

During the tour most of the travellers mutually communicated the awe of 'being there', visiting the holy land and the sites of the national myth. This 'affective atmosphere' (Anderson 2009) was also heightened by the sense of imminent danger. Most of the monuments visited were either damaged or completely devastated and afterwards rebuilt during the 2004 unrest in Kosovo (the mass violence of Albanians against the Serbian population, which is also widely known in Serbian media as the 'March Pogrom'). The state of threat was clearly outlined by the presence of a police escort, which was announced beforehand by the organizer. The incident with the bus breakdown in Drenica and the atmosphere while visiting the church of Samodreža and the church in the city of Peć also brought forward the security threats. The sense of being on inhospitable land was also fostered by Albanian national symbols and Islamic landmarks, which were omnipresent on the road from one Serbian enclave to another.

15 Gazimestan is a memorial complex, with a monument in the shape of a stylized medieval tower, dedicated to the site of the medieval Battle of Kosovo in 1389, built in 1953. 


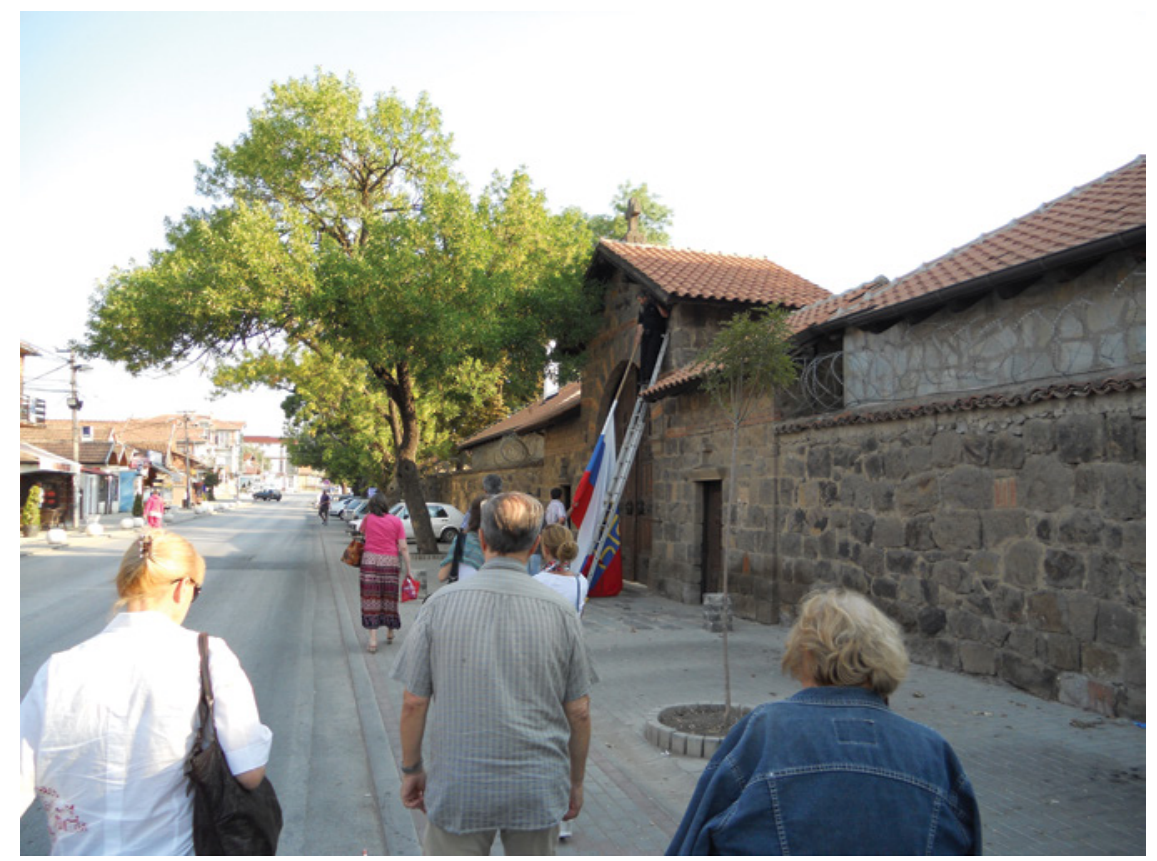

ILLUSTRATION 2 Pilgrims visiting the monastery of Gračanica, with Serbian flags stacked in front of the monastery's courtyard doors.

PHOTO BY THE AUTHOR

Specific bodily practices also heightened the intensity of affective experience during the pilgrimage. The trip was organized during the fasting, and many pilgrims anxiously observed strict religious food protocols, questioning even the food that was served by the monks. Scarcity of food on the trip was also an issue because the tour did not stop anywhere but in Serbian enclaves and communication with the Albanian population was prohibited, which meant that often groceries could not be obtained. ${ }^{16}$ In this way the observance of religious canons and the presence of constant national conflict directly affected the bodies of the pilgrims, heightening the level of the experience. The unvoiced fear and the transmuted body set the stage for the community of affect (on fear and affect cf. Massumi 1993, 2010).

16 This provoked a disquieting verbal incident, when few travellers went to an Albanian food store when visiting the church in the city of Peć. 


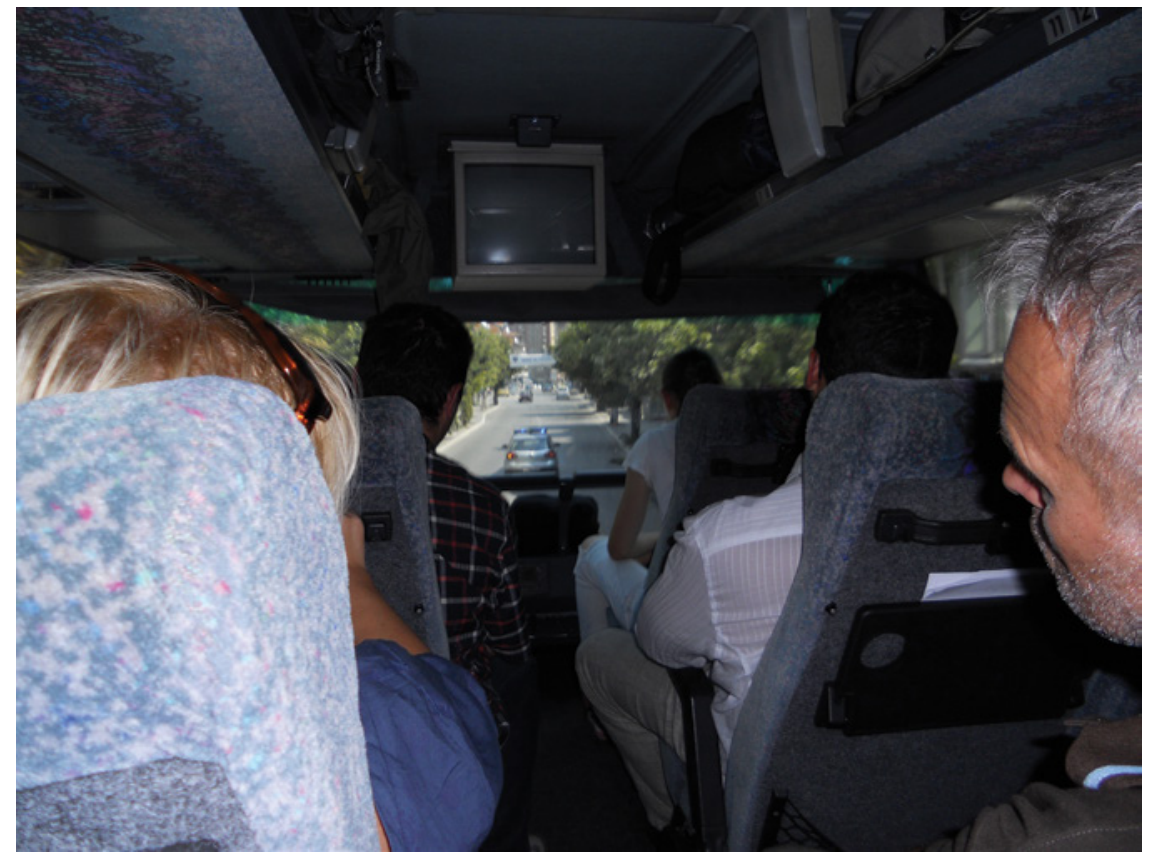

ILLUSTRATION 3 The view from the upper floor of the bus on the move, with the police escort visible ahead of the bus.

PHOTO BY THE AUTHOR

\section{The Sound of Memory}

Scene 4. Sunday morning. Hastily we run towards the gateway of the monastery guarded by the distrustful Italian soldiers. The women hurriedly don long skirts and put scarfs over their heads, lest they be deemed as unbecomingly dressed. We enter the serene courtyard of the Visoki Dečani monastery, sloping around the fourteenth-century church coated with intricately marbled yellow and violet stone. Entering the parvis while performing the sign of the cross, we push through and towards the crowded five-nave cella. While our eyes become accustomed to the dim lighting reliant upon the candles and the shafts penetrating through narrow crevice-like windows in the thick walls of the medieval church, the acoustic reverberating sound of the monks' chant ushers us into this other-worldly sensuous experience bereft of the props of electronic technology. The monks bring up the resuscitated 'Serbian Byzantine chant', which they are famous for perfecting with their strong, male, decisive, non-vibrato voices. Few are conversant with the meanings of their 
daedal ritual, including responsorial and antiphonal singing, small processions, the swaying of the chandelier, the use of incense, and the ending ceremonial of extinguishing the candles, but it is still the object of engrossment for all.

A growing body of scholarship has been pointing to the pertinence of sound and music in the perception of space (Jazeel 2005). Investigating the intrinsic performative nature of music (even when understood as reproduced recording) and the spatial nature of sound, which always appear as a part of a certain soundscape, one can discuss both music and sounds as auditory technologies of placement that serve to situate and direct the individual through the processes of subjectification. More than an image, which can remain static, sound imbues the landscape with motion and changeability, forcing the individual to engage bodily and affectively with the environment (cf. Rodaway 1994: 82-7). Conceptualizing the soundscape as the 'sonic environment which surrounds the sentient' (Rodaway 1994: 86), one is also impelled to violate the delicate and fragile line that separates 'sound' as a physical and 'music' as an aesthetic experience, as the latter comes to encompass all the sonic events that are construed as meaningful due to cultural discourses, but also relying on our previous experiences. Auditory experience thus appears as a move through various musical artefacts, which act as sonic palimpsests, with meaning being constantly re-inscribed through spatial situations in which one encounters them. This differential relation between music and space thus appears as a twofold production of meaning. Concentrating on music in my account as both bodily and spatial, but also as a repository of meanings of past and present, I wish to explore the potential of a music event to enact, embody, and spatialize memory.

Musical events, which formed part of the pilgrimage as a physical experience, can be divided into three categories. The first is the music played in the bus, as part of the trip, selected by the leader and organizer of the trip. The second is the music that participants themselves individually chose to listen to during the trip on their portable media players, as well as the music they performed (sang) on the bus. The third category constitutes the performance that pilgrims visited on their trip, namely, the Great Service on the Sunday morning in the Visoki Dečani monastery. The music on the bus consisted exclusively of sacred music while within the borders of Kosovo, and of patriotic and folk songs once the bus entered Serbia proper. Most of the travellers reacted to the sacred music as being 'appropriate' and 'surprisingly beautiful'. Only a small number of participants carried portable media players. However, studying the music they listened to shows that the effort of creating a personal musical 
choice and carrying the portable media players was not done in a subversive effort to counteract the dominant soundscape, but rather to control even further the economy of affects to which they exposed themselves. There was a surprising congruity between the three categories of music, as the music on the portable players also fit into the genres of sacred or patriotic music, and the chants of the monks from Visoki Dečani were present (and prominent) in all three categories. The production of affective economies through music thus escaped the strict dualism between 'top-to-bottom' and 'grassroots,' which one is often impelled to apply when categorizing social phenomena. The specific affective economy is created in the equilibrium where many parallel processes of subjectification intersect, and it heightens -even maximizes- the lived intensity. The position of the organizer of the trip is thus not that of an ideological leader or a sinister mastermind, but merely of another haecceity, 'thisness' constituted on a different, quasi-arborescent placein this desiring-machine (cf. Deleuze and Guattari 1987: 14-16, 260-63).

The most prominent element of the pilgrimage's soundscape in Kosovo was the so-called 'Byzantine chant,' which was predominately played during the time the bus was in the very territory of Kosovo, and which was also the most striking part of the liturgy in Visoki Dečani. Proponents of the 'Byzantine chant' revival have argued that this chant, unlike the choral practices based on Western harmony and mostly introduced during the nineteenth century, represents a more ancient tradition that can be traced back to the first centuries of Christianity, and therefore embodies the 'true' values of Orthodox Christianity (cf. Peno 2005, Zirojević 2010). Basing their practices heavily on the living Greek tradition, as well as on the surviving Greek and Romanian sources, the proponents of the 'Byzantine Chant' revival in the ranks of clergy have not only argued for a discontinuation with choral, harmonized church music, but have also eschewed the Serbian tradition of monodic chant written down in the nineteenth century by composers such as Kornelije Stanković, Stevan Stojanović Mokranjac, and Nenad Barački.

During the 1990s the movement was articulated through private choir initiatives adjacent to several church communities in Belgrade that practiced Byzantine chant, as well as by the monastic communities in Serbian Orthodox monasteries such as Kovilj in Vojvodina and Visoki Dečani in Kosovo. Besides several audio recordings published by these communities, foreign recordings have proved to be very popular, especially of Greek and Russian provenance. During the 2000s, the authorities of the Serbian Orthodox Church enforced stricter regulations on music in the churches in an attempt to purge the service of Byzantine chant and to adhere to the Serbian Church music tradition, but the movement continued to thrive, with an increasing number of the young 
priests interested in its practices (Zirojević 2010). The musical characteristics that the devotees singled out as particularly important in their appreciation of the 'Byzantine chant' include repetitive melodic formulas, monophony, a nontempered scale, a vocal performance style deprived of vibrato, and, most importantly, the ubiquitous presence of ison, a vocal drone that usually remains static throughout a chant, giving a recognizable cachet to this music genre. Together with a reverberation effect, which is strongly emphasised on all the recordings and also experienced in the highly acoustical ambient of the monastic church of Visoki Dečani, these musical characteristics impart a sense of otherworldliness and timelessness to the audience. Although the discourse surrounding the 'Byzantine chant' revival movement relies on the tropes that supposedly transcended questions of nationalism, the lived experience of this pilgrimage overrides this purport, as the music was used to map Kosovo as a Serbian 'holy land,' in resonance with the rhetoric of Serbian nationalism. Thus, the meaning of the music was not simply decoded in the moment of the performance, but it was produced and embedded in specific situations and influenced by the intensity of the affective experience in situ.

Specific patriotic songs present on this trip also acted as artefacts of memory, placed in the space through their performance on the move. These songs were played on the last evening of the trip, when the bus had exited the 'sacred space' of Kosovo, ushering in a more profane atmosphere of revelry. In order to understand how these songs act as 'lieu de memoire' it is not sufficient to read them as 'texts', interpreting their meaning through the verses or even their musical style. Instead, we need to reconsider them as mnemonic palimpsests, ambiguous musical objects with lives of their own, which accumulate and produce memories through their own encounters and the contexts in which they have been perused.

Accordingly, I will discuss the first three songs that were played on the bus just after leaving Kosovo - Vidovdan, Srpska se truba s Kosova čuje, and Ječam žnjela Kosovka devojka - which are unquestionably a part of the core of folk-patriotic repertoire. The first of the songs, Vidovdan ('St Vid's Day'), was composed by Milutin Popović Zahar and it was initially performed by Gordana Lazarević in connection to the 1989 celebration of the anniversary of the Kosovo Battle. Belonging to the (officially decried) genre of 'newly composed folk music,' the song swiftly gained immense popularity, becoming a staple of "entertainment repertoire" performed in pubs and both on informal celebrations and patriotic occasions. In regards to the latter, the song is ubiquitously present at all nationalistic rallies in Serbia, especially in connection to the Kosovo issue. The verses of the song are especially poignant, as they create a sense of timelessness and speak of the protagonist's primordial connection 
with the land of Kosovo ('As the eternal flame in our hearts / The truth of the Kosovo Battle remains / Wherever I go I come back to you / Who could steal Kosovo from my soul'). ${ }^{17}$ The highly expressive and striking interpretation of Gordana Lazarević has become synonymous with the song, and this rendition was also the one heard on the bus. Lazarević uses a vocal style that emphasizes the narrative, verbal content in the strophes, and the strenuous, highly expressive 'virtuoso outcry' in the refrain, specifically on the word 'Vidovdan,' which opens and closes the song. Due to these 'outcries' and the overall musical contours of the song, with the highly climactic hymnic refrain repeated three times, the song is especially modelled to provoke affective responses from the audience.

The song Srpska se truba s Kosova čuje ('The Serbian trumpet resounds from Kosovo'), the second one to be played after leaving the 'sacred' territory of Kosovo, was also the only song played on the bus to be greeted with applause, and it was additionally present on the personal players of the travellers. Although purportedly a folk song, it is not present in folk-song collections predating the Second World War, and this kind of repertory would not have been allowed in the first decades of socialist Yugoslavia. Praising the Serbian 'reconquista' of the Balkan Wars, Linguist Svetozar Stijović licentiously surmised that 'the song was created after the final expulsion of the Turks from Serbian settlements and the liberation of the scene of the most famous battle in the Serbian history, in 1912,' as an expression of delight when, 'after five centuries of slavery', for the first time one could hear the 'joyful trumpet.' The tune was written down in 1971 by the composer and clarinettist Radoje Koteski, who is also responsible for arranging this relatively simple march-like tune in the manner that stylistically fits the 'newly composed' repertory of the 1970s, albeit adding an unusual fanfare motive played on trumpet both as an introduction and as an interlude between the stanzas. The song became popular after it was played in the film Kuća pored pruge (1988), ${ }^{18}$ and after an audio cassette entitled Niko nema što Srbin imade ('No one has what the Serbian does') was issued in 1989 on the occasion of the Kosovo Battle anniversary. On the cassette it was performed by members of the Orthodox clergy (namely, by Radomir Perčević, and the profit was intended to support the building of the Saint Sava Temple in

17 Ko večni plamen u našim srcima / Kosovskog boja ostaje istina / Kud god da krenem tebi se vraćam ponovo / Ko da mi otme iz moje duše Kosovo.

18 Directed by Žarko Dragojević, the film Kuća pored pruge dealt with a Serbian family that escapes Kosovo after being molested by Albanians who ultimately raped the daughter in the presence of her mother. 
Belgrade).${ }^{19}$ Interpretations by others followed, notably by Radiša Urosević, and the song has come to be associated with the repertoire of Chetniks' songs and is now mainly found on CD compilations of 'patriotic songs', which are widely available for purchase. ${ }^{20}$ The lines of the song narrate the 'liberation' of the Kosovo field and revenge against the oppressor, and make references to medieval Serbian heroes, creating a sense of racial community. ${ }^{21}$ The performance of the song in this group setting triggered the narratives of mutual suffering, revenge, and national pride, creating collective bodily responses and provoking pilgrims to sing along, applaud, and gesture.

The third song, Ječam žnjela Kosovka devojka ('A girl from Kosovo reaped the Barley'), is also usually advertised as a traditional folk song (however, I could trace no concrete ethnomusicological transcriptions). Unlike the previous song, except for a simple mention of Kosovo, it does not express any openly nationalistic sentiments, and its performances were unhindered throughout the socialist period in Yugoslavia. The verses performed in the Yugoslav period centred on the young female character, who obliquely speaks of her longing to get married. ${ }^{22}$ The first prominent recording was made by Mara Đorđević and the ensemble of Radio Television Belgrade in 1960, and the same verses can be found in subsequent interpretations by singers such as Merima Njegomir, Vasilija Radojčić, and others. However, although these love verses remain present, in recent years some verses have been supplemented by indirectly belligerent

19 Data on the song was tracked in the records of Radio Beograd. I wish to thank Mirjana Drobac for help in obtaining this information.

2o The so-called repertoire of Chetniks' songs gained popularity in the gos, encompassing many of the songs that were (officially or tacitly) banned during the rule of the communist party, and which are thematically linked to the Chetnik movement, nationalist and monarchist paramilitary organizations whose alleged anti-Axis alignment has been officially asserted in the 200os, not without the outrage of a part of the Serbian intellectual elite (among the most outspoken being Zagorka Golubović, Dubravka Stojanović, etc.; cf. Stojanović 2010: 132-7). The mainstream songs of the Chetniks' repertoire were also present on the margins of the pilgrimage, being occasionally sung by the individual travellers or smaller groups, and being present on the personal music players.

21 'Serbian trumpet resounds from Kosovo / and every Serb rejoices with its sound. / Blow brothers, more powerful, better, / Kosovo Polje is Serbian again' ('Srpska se truba s Kosova čuje, / Srbina svakog da obraduje. / Trubite braćo, silnije, bolje, / opet je srpsko Kosovo Polje.').

22 'Kosovo girl reaped the barley / she reaped it, she spoke to it: / "barley grain, noble seeds / I reap you, though I don't eat you! / The wedding guest's horses shall feed on you / either mine or my brother's / better mine than my brother's”' ('Ječam žnjela Kosovka devojka / ječam žnjela, ječmu govorila: / "Ječam žito, seme plemenito / ja te žela, a ja te ne jela! / Svatovski te konji pozobali / Ili moji, ili brata moga / bolje moji, nego brata moga"'). 
ones, which speak of the 'Serbian army returning to Kosovo', with the additional listing of prominent Serbian monuments, all of which were also present along the route of the pilgrimage. ${ }^{23}$ Reportedly, one of the first performances in which this doctored text could be heard took place at the rally organized in protest of Kosovo's proclamation of independence in February 2008. ${ }^{24}$ Interestingly, these verses have been publicly performed by one of the leading clerics of the Serbian Orthodox Church, Metropolitan Amfilohije (Risto Radović). ${ }^{25}$

Thus, the performance of the aforementioned songs in the bus leaving the sacred ground of Kosovo did not only generate an ambiguous nationalistic sentiment and provoke affective responses from the pilgrims who could finally indulge in profane entertainment; rather, it was also a moment of bringing the complex assemblage of memories into the lived immanence of the immediate experience. The nationalist assemblage not only regulated the pilgrims' quotidian discourse and their openly expressed opinions, it also regulated their enjoyment, providing a purview of musical objects that they could appreciate. Thus, in the moments when the bodies of the pilgrims were seemingly most deterritorialized, flying towards pure enjoyment and intoxication, they were effectively transformed into the body of the nation and constituted as national subjects. Through the revelry itself, therefore, religious nationalism was inscribed and the body was reterritorialized. ${ }^{26}$

23 'Noble horses will feed on you / Black horses of the glorious Serbian army / when army returns to Kosovo / and waters the horses at the river Sitnica / and rides over Gazimestan / and rides towards glorious Dečani / and to the imperial laura of Gračanica / and to Prizren, the emperor's city / all in the glory of the almighty God' ('Viteški te konji pozobali / Vrani konji slavne srpske vojske / Kad se vojska na Kosovo vrati / i napoji konje na Sitnici / i pojezdi po Gazimestanu / i pojezdi do slavnih Dečani / i do carske lavre Gračanice / i Prizrena, grada carevoga / sve u slavu Boga velikoga').

24 The central rally was organized by the Serbian government in Belgrade on February 21, under the slogan Kosovo je Srbija ('Kosovo is Serbia'), and was held in front of the Parliament, reportedly with up to 500,000 people attending. It was followed by the religious service of mass supplicatory prayer (moleban) in front of St. Sava Temple, but also with violent outbursts throughout the city, particularly targeting foreign embassies.

25 Particularly noteworthy was his performance at the feast of Epiphany (Krstovdan) in January 2010, where he was joined by opera singer Oliver Njego. The celebrations of Epiphany, featuring a swim race in cold winter rivers, regularly provide paradigmatic instances of combining religious and national imagery. In this particular performance, the crowd awarded applause to specifically poignant verses that were added to the song.

26 As Deleuze and Guattary (1987:54) insist, 'deterritorialization must be thought of as a perfectly positive power that has degrees and thresholds (epistrata), is always relative, and has reterritorialization as its flipside or complement'. 


\section{The Dialectics of Space: Producing the Nation and the Sacred}

Scene 5. Sunday early evening. We are leaving the last stop on the trip, the church of Saint Vasilije in Leposavić. Soon after one of the travellers starts singing patriotic songs. Others join in singing the 'Saint Sava Hymn'. His performance is greeted with a hearty applause. At 8:20 we leave the 'administrative checkpoint' and enter Serbia proper. The leader of the trip now plays popular patriotic and folk songs in the bus - Vidovdan, Srpska se truba s Kosova čuje (followed with applause), Ječam žnjela Kosovka devojka,... While few join in the songs, and that only occasionally, the atmosphere becomes pronouncedly jovial. Notwithstanding the 'rules of behaviour', some consume alcohol and a few become rather intoxicated.

Producing the 'representational space' of the nation and of the sacred through music and sound is an open process of affective juxtaposition of subjects' actual spatial practice with the corresponding 'representations of space'. As such, 'representational space', the 'lived abstraction' (Massumi 2002: 177), is also ultimately a space of affects, as its existence as a virtual entity is perpetually dependant on the constant flow of affects, which are being produced through the intersection of spatial practice and 'representations of space'. The production of the 'representational space' thus cannot be achieved simply by the semantic of the sound, but also requires its excessive intensities -the intensity seemingly not needed to transmit the 'message' itself- which allow the meaning to be inscribed on the body, simultaneously creating and becoming an embodied memory as such. Finally, I would argue that this immanence of the 'representational space' serves as the vehicle for the hybridization of affect. It is therefore through its materiality and the artifactuality of the 'representational space' that the feeling of 'being there', the national sentiment, and the religious body are lived through as a hybrid univocity.

Through the lived space, nation and religion appear not as (transcendent) ideas or ideologies that the subject chooses to accept or reject, and they do not remain alien to the subject's body, but instead they themselves appear as an inextricable part of his or her affective capacities. Affects are produced as the excess intensity where the virtual of the nation and religion encounters the actual (cf. Massumi 2002); they are the product of (virtual) religious nationalism's ability to affect the actual, and the actual affective practice to fold and ply the virtual, creating lines of flight in the spaces of ambivalence and incongruity. The nature of these affects is always social, as producing the space of religious nationalism is never a matter of the individual nationalistic subject. 
Affects are not merely transmitted; rather, they transcend the subject, which is reduced merely to a haecceity. ${ }^{27}$

My task has been to study how the specific economies of affects -transmitted through common musical and spatial experience, gestures, and utteranceslead to the social production of religious nationalism, how they constitute Kosovo as both sacred space and the core territory of the Serbian nation on the level of the lived space. In lieu of a conclusion, I will try to show how the Lefebvrian tri-dimensional dialectic occurs on the molecular level, and will illustrate its three modalities of space as they occurred on the pilgrims' route. The level of spatial practice is present in the pilgrims' quotidian exigencies of their 'brute mobility' and their sense of 'being there.' It is the level of the 'perceived space' that is yet to affect their experience. ${ }^{28}$ It is the space of mobility that brings them to perceive the change in the landscape they interpreted as 'holy' or 'spiritual,'29 or the garbage being littered along the road that they interpreted as the mark of alien, non-Christian culture.

The 'representation of space' was demonstrably present in the music being played on the bus, as the musical genres present in the playlist dramatically changed with the change of territory. In the first phase of the trip, before entering Kosovo, music was 'unmarked,' consisting of customary radio stations playing moderately mainstream pop music, or it was simply absent, as most of this part of the trip took place during the night. As the bus entered Kosovo, the music became exclusively sacred, of Orthodox Christianity. Even more specific, the music that was played at this point mostly belonged to the above-mentioned 'Byzantine chant,' a movement struggling to reject the Western-influenced choral singing in the Orthodox churches, aiming to rejuvenate the practice of melismatic chant accompanied by ison (drone note), and mostly relying on present musical practices in the Greek Orthodox Church.

27 For the concepts of transmission of affects and shared affective economies see Brennan 2004 and Ahmed 2004. Seyfert (2012) poignantly demonstrates the inter-corporeal nature of affect and shows how, in order to understand the ontology of affect, we also have to understand the concept of body in Spinozistic terms, where the two are incessantly connected through the body's capacity to affect and affect's capacity to mutate the body; introducing the term affectif, Seyfert strives to capture the totality of this body-affect relation in a given social situation.

28 On the importance of encounter for sensibility cf. Deleuze (1994: 139-40) and Seyfert (2012: $38-9$ ), who draws on Jean-Marie Guyau in describing types of affective interactions. Specifically, Lori G. Beaman (2006) shows how mobility and 'the confluence of body and space' present an important prerequisite for the religious experience and 'the intersection of memory and space'.

29 For the pilgrims' experience of landscape cf. Cooper 1994. 
The pilgrims listened to recordings of the monks of Visoki Dečani performing Paraklesis to the Holy King Stefan of Dečani, ${ }^{30}$ as well as recordings of the Greek monks from The Holy Monastery of Varlaam and other similar recordings, but also listened to Russian songs on paraliturgical verses.

This austerity of music choices, the self-imposed and attentively confined economy of sonic affects, can be contrasted with the third phase, which was unleashed upon leaving the territory of Kosovo. Here, popular patriotic songs and folk songs were played, most of which were written or rearranged in the late 1980 in the current style of 'newly composed folk music.' Unlike the sacred music played while in the territory of Kosovo, this repertory creates a completely different affective economy, inviting travellers to participate and revel. We can see that, through the specific schedule of music played on the bus, Kosovo is being mapped as a sacred space and a specific type of behaviour is therefore shaped. Moreover, the sacred music becomes the soundtrack of the Kosovo landscape, the cognitive filter through which the space is represented in the experience of the pilgrims. Their situation is specific as they cruise the territory of Kosovo, forging from one Serbian enclave to another while crossing land marked by the presence of people they openly detest. They live through a mediated image of the land, an image created by the specific mobility of the tour that accentuates the Serbian presence and by the soundscape of sacred music.

Music thus effectively becomes the conceived space: the sacred music did not make blunt references to Kosovo as the holy Serbian land, and it was only in the act of its performance/playing, paired with the pilgrims' mobility, that the level of the conceived space was realized. Music then created a filter of sorts, an interpretative apparatus through which the pilgrims experienced the space and reality around them. This filter led to representing the space of Kosovo in a 'timeless' quality, positioning it in the utopian past as allegedly forming the core of the Serbian homeland.

Finally, the lived space is realized in intensities produced when the perceived and conceived space juxtapose, in the molecular cuts where one's subjectivity is reterritorialized. When the bus climbed on its way to the monastery of Gorioč, the penultimate stop on the tour and the last that was enclaved, a pious companion looked at the landscape that opened though the window and quietly noticed: 'Indeed, Kosovo field is of a shape like a heart'. In this sentence, he did not simply reiterate the Serbian nationalistic discourse that 'Kosovo is the heart of Serbia', but he brought this phrase to the level of mantra - he lived it, he 'was there', and he affectively engaged with the space using the representations that

3o The CD Molebni kanon Svetom kralju Stefanu Dečanskom was issued by the Visoki Dečani monastery in 2007. 
were already embedded in it. He lived the abstraction in its transience and immediacy (cf. Massumi 2002: 4-5) and the abstraction became inscribed in his body - not in the outwardness of his constitution, but in the totality of his somatic structure, which learns how to react in specific ways and to produce intensities in certain situations. He realized his conatus through engaging with nationalism not as an ideology but as a desiring-machine, and he showed his willingness to participate in the shared affective economy by limiting his actions, exposing himself to particular sensations, and conducting specific body management (cf. Rasmussen 2011: 24-25). He himself thus became lieu de memoire,' through a process of physical inscription and not of transcendent symbolic production (cf. Clastres 1973). And while his lived experience always remains open and ambiguous, in this case the strength of religious nationalism has been exercised through its capacity to produce intensities and to hybridize the affects (of religious piety and national pride, but of seemingly pure bodily indulgence as well), reterritorializing the molecular cravings of the individual.

\section{Bibliography}

Ahmed, S. 2004. 'Affective Economies', Social Text 22: 117-39.

Anderson, B. 2009. 'Affective atmospheres', Emotion, Space and Society 2: 77-81.

Bakić-Hayden, M. 2010. 'St. Sava and the Power(s) of Spiritual Authority', Serbian Studies 24: 49-62.

Beaman, L.G. 2006. 'Labyrinth as Heterotopia: The Pilgrim's Creation of Space', in W.H. Swatos Jr. (ed.), On the Road to Being There. Studies in Pilgrimage and Tourism in Late Modernity (Leiden and Boston: Brill): 83-103.

Belaj, M. 2012. Milijuni na putu. Antropologija hodočašća i sveto tlo Međugorja (Zagreb: Jesenski i Turk).

Brennan, T. 2004. The Transmission of Affect (Ithaca and London: Cornell University Press).

Brown, P. 1988. The Body and Society: Men, Women, and Sexual Renunciation in Early Christianity (New York: Columbia University Press).

Brubaker, R. 2011. 'Religion and nationalism: four approaches', Nations and Nationalism 18: 1-19.

Brubaker, R. and F. Cooper. 2000. 'Beyond "Identity", Theory and Society 29: 1-47.

Carrette, J.R. 1999. Foucault and Religion. Spiritual Corporality and Political Spirituality. (London: Routledge).

Clastres, P. 1973. 'De la Torture dans les sociétés primitives', L'Homme 13: 114-20.

Coleman, S. 2002. 'Do you believe in pilgrimage? Communitas, contestation and beyond', Anthropological Theory 2: 355-368. 
Coleman, S. and J. Eade (eds.). 2004. Reframing Pilgrimage: Cultures in Motion (London: Routledge).

Cook, T. 2011. 'Conatus: A Pivotal Doctrine at the Center of the Ethics', in M. Hampe, U. Renz and R. Schnepf (eds.), Spinoza's Ethics: A Collective Commentary (Leiden and Boston: Brill): 149-166.

Cooper, A. 1994. 'Landscape, Place and Personal Pilgrimage Experience', in S.M. Bhardwaj, G. Rinschede and A. Sievers (eds.), Pilgrimage in the Old and New World (Berlin: Dietrich Reimer Verlag): 81-93.

Cresswell, T. 2006. On the Move. Mobility in the Modern Western World (New York and London: Routledge).

Deleuze, G. 1988. Spinoza: Practical Philosophy, trans. R. Hurley (San Francisco: City Lights Books).

. 1990. Expressionism in Philosophy: Spinoza, trans. M. Joughin (New York: Zone Books).

-1994. Difference and Repetition (New York: Columbia University Press).

Deleuze, G. and F. Guattari. 1983. Anti-Oedipus. Capitalism and Schizophrenia (Minneapolis: University of Minnesota Press).

- 1987. A Thousand Plateaus. Capitalism and Schizophrenia (Minneapolis and London: University of Minnesota Press).

1994. What is Philosophy? (New York: Columbia University Press).

Eade, J. and M. Sallnow (eds.). 1991. Contesting the Sacred:The Anthropology of Christian Pilgrimage (London: Routledge).

Friedland, R. 2001. 'Religious Nationalism and the Problem of Collective Representation', Annual Review of Sociology 27: 125-52.

Goonewardena, K., S. Kipfer, R. Milgrom and C. Schmid (eds.). 2008. Space, Difference, Everyday Life. Reading Henri Lefebvre (New York: Routledge).

Haag, J.W. and W.A. Bauman. 2012. 'De/Constructing Transcendence: The Emergence of Religious Bodies', in D. Cave and R.S. Norris (eds.), Religion and the Body. Modern Science and the Construction of Religious Meaning (Leiden: Brill): 37-55.

Ivakhiv, A.J. 2001. Claiming Sacred Ground: Pilgrims and Politics at Glastonbury and Sedona (Bloomington: Indiana University Press).

Jazeel, T. 2005. 'The world is sound? Geography, musicology and British-Asian soundscapes', Area 37: 233-41.

LeBuffe, M. 2014. 'Spinoza's Psychological Theory', in E.N. Zalta (ed.), The Stanford Encyclopedia of Philosophy (Spring 2014 Edition). <http://plato.stanford.edu/ archives/spr2014/ entries/spinoza-psychological/>.

Lefebvre, H. 1991. The Production of Space (Oxford: Blackwell).

Lordon, F. 2014. Willing Slaves of Capital. Spinoza and Marx on Desire, trans. G. Ash (London and New York: Verso). 
Malešević, M. 2011. 'Pravoslavlje kao srž "nacionalnog bića” postkomunističke Srbije', in Ima li nacija na planeti Ribok? Ogledi o politikama identiteta (Beograd: Srpski genealoški centar): 71-100.

Maliqi, Shkëlzen. 2011. Shembja e Jugosllavisë dhe rrëfime të tjera politike, interview by Baton Haxhiun (Tiranë: UEt Press). Trans. by A. Berišaj as Kosovo iraspad Jugoslavije (Beograd: Radnička komuna Links and Mostart, 2014).

Massumi, B. 1993. 'Everywhere You Want to Be. Introduction to Fear', in B. Massumi (ed.), Politics of Everyday Fear (Minneapolis, London: University of Minnesota Press): $3-37$.

2002. Parables for the Virtual. Movement, Affect, Sensation (Durham and London: Duke University Press).

- 2010. 'The Future Birth of the Affective Fact: The Political Ontology of Threat', in M. Gregg and G.J. Seigworth (eds.), The Affect Theory Reader (Durham and London: Duke University Press): $5^{2-70 .}$

Mitrović, M. 2011. 'The "Unbearable Lightness" (of the Subversion) of Nationalism: Bodies on Estrada in Postsocialist Serbia', Bulletin of the Institute of Ethnography SASA 59: 137-48.

Nora, P. 1989. 'Between Memory and History: Les Lieux de Mémoire', Representations 26: $7-24$.

Parr, A. (ed.). 2005. The Deleuze Dictionary (New York: Columbia University Press).

Peno, V. 2005. 'Vizantijsko crkveno pojanje - božanska pevana reč', Stanje stvari 11: 229-41.

Purcell, M. 2013. 'Deleuze \& Guattari, Lefebvre, and Radical Democracy', paper read at The Sixth International Deleuze Studies Conference The Territory In-Between. The Centre for Philosophy of Sciences of the University of Lisbon, 8-10July, 2013. < http:// pathtothepossible.wordpress.com/2013/07/23/deleuze-guattari-democrats/> [accessed 24 Jul 2013].

Radisavljević Ćiparizović, D. 2010. Pilgrimages, Cult Places and Religious Tourism, Niš: Yugoslav Society for the Scientific Study of Religion.

- 2012. 'Religioznost hodočasnika u Srbiji: studija slučaja tri svetilišta', Filozofija $i$ društvo 23: 53-68.

Radulović, L. 2010. 'Feminizacija hodočašća u kontekstu revitalizacije religije u Srbiji', Antropologija 10: 39-48.

Rasmussen, C.E. 2011. The Autonomous Animal Self-Governance and the Modern Subject (Minneapolis and London: University of Minnesota Press).

Rocca, M.D. 1996. 'Spinoza's metaphysical psychology', in D. Garrett (ed.), The Cambridge Companion to Spinoza (Cambridge: Cambridge University Press): 192-266.

Rodaway, P. 1994. Sensuous Geographies. Body, Sense and Place (London: Routledge). 
Seyfert, R. 2012. 'Beyond Personal Feelings and Collective Emotions: Toward a Theory of Social Affect', Theory, Culture \& Society 29: 27-46.

Sikimić, B. 2014. 'Sveta putovanja: Letnica na Kosovu', Glasnik Etnografskog instituta SANU 62: 15-32.

Stojanović, D. 2010. Ulje na vodi. Ogledi iz istorije sadašnjosti Srbije (Beograd: Peščanik).

Sundhaussen, H. 2007. Geschichte Serbiens. 19.-21.Jahrhundert (Wien, Köln and Weimar: Böhlau Verlag).

Thompson, M. and I. Biddle (eds.). 2013a. Sound, Music, Affect: Theorizing Sonic Experience (New York and London: Bloomsbury).

- 2013b. 'Introduction: Somewhere between the signifying and the sublime', in Thompson and Biddle 2013a: 1-24.

Turner, V. 1973. 'The Center out There: Pilgrim's Goal', History of Religions 12, no. 3: 191-230.

Turner, V. and E. Turner. 1978. Image and Pilgrimage in Christian Culture. Anthropological Perspectives (New York: Columbia University Press).

White, G.W. 2000. Nationalism and Territory: Constructing Group Identity in Southeastern Europe (Rowman \& Littlefield Publishers, Lanham).

Zirojević, I. 2010. An interview conducted through e-mail correspondence. <http:// pevnica.wordpress.com/2010/12/28/intervju/> [accessed 3 June 2013]. 